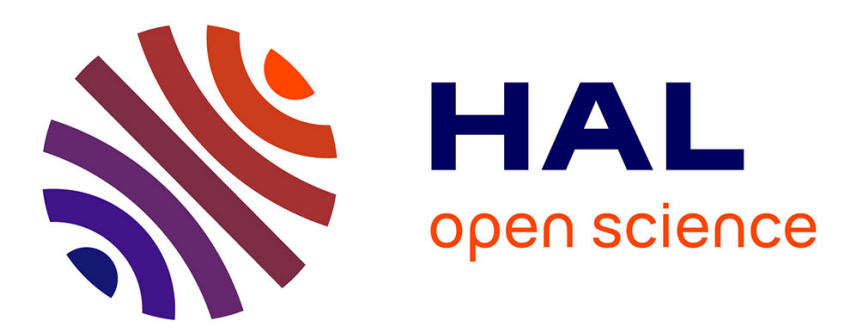

\title{
Chemical composition and distribution of tattoo inks within tattoo-associated keratoacanthoma
}

\author{
H. Colboc, D. Bazin, P. Moguelet, S. Reguer, R. Amode, C. Jouanneau, I. \\ Lucas, L. Deschamps, V. Descamps, N. Kluger
}

\section{- To cite this version:}

H. Colboc, D. Bazin, P. Moguelet, S. Reguer, R. Amode, et al.. Chemical composition and distribution of tattoo inks within tattoo-associated keratoacanthoma. Journal of the European Academy of Dermatology and Venereology, 2020, 34 (7), pp.e313-e315. 10.1111/JDV.16220 . hal-03269990

\section{HAL Id: hal-03269990 https://hal.science/hal-03269990}

Submitted on 8 Jul 2021

HAL is a multi-disciplinary open access archive for the deposit and dissemination of scientific research documents, whether they are published or not. The documents may come from teaching and research institutions in France or abroad, or from public or private research centers.
L'archive ouverte pluridisciplinaire HAL, est destinée au dépôt et à la diffusion de documents scientifiques de niveau recherche, publiés ou non, émanant des établissements d'enseignement et de recherche français ou étrangers, des laboratoires publics ou privés. 


\section{Article type: Letter to Editor}

\section{Chemical composition and distribution of tattoo inks within tattoo associated}

\section{keratoacanthoma.}

Keywords: keratoacanthoma; azo pigment; Synchrotron radiation techniques; Raman spectroscopy; tattooing

Manuscript word count: 562/600; Figure count: $2 / 2$

H Colboc ${ }^{1}$, D Bazin ${ }^{2}$, P Moguelet ${ }^{3}, \mathrm{~S}$ Reguer $^{4}$, R Amode ${ }^{5}$, C Jouanneau ${ }^{6}$, I Lucas ${ }^{7}$, L Deschamps $^{8}$, V Descamps ${ }^{5}$, N Kluger ${ }^{5,9}$

${ }^{1}$ Sorbonne Université, Wound Healing Department, Rothschild Hospital, Paris, France

${ }^{2}$ CNRS, LCP, Ba340, Paris XI University, 91405 Orsay, France

${ }^{3}$ Sorbonne Université, Department of Pathology, Tenon Hospital, Paris, France

${ }^{4}$ Diffabs beamline, Synchrotron Soleil, Synchrotron SOLEIL L'Orme des Merisiers SaintAubin, BP 4891192 Gif-sur-Yvette Cedex, France

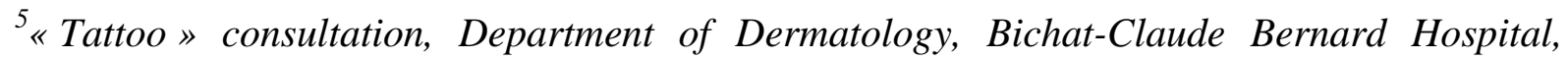
HUPNVS, Paris, France

${ }^{6}$ Sorbonne Université, UMRS 1155, Tenon Hospital, Paris, France

${ }^{7}$ Sorbonne Université, UMR 8235, Paris, France

${ }^{8}$ Department of Pathology, Bichat-Claude Bernard Hospital, HUPNVS, Paris, France

${ }^{9}$ Department of Dermatology, Allergology and Venereology, Helsinki University Hospital, Helsinki, Finland 


\section{Correspondence}

Dr Hester Colboc, APHP, Service Plaies et Cicatrisation, Hôpital Rothschild, 5, Rue Santerre, 75012 Paris, France. E-mail: hester.colboc@aphp.fr

Phone: 0033603611623

\section{Funding sources: None}

Conflicts of interest: None declared

Word count: 562/600

Carcinogenic risk of tattoo inks remains unclear and their composition are poorly regulated. Various types of carcinogenic compounds can be found in tattoo inks, including primary aromatic amines (PAA), cleavage products of organic azo-colorants, found in colored inks. ${ }^{1}$ Many cases of skin cancers occurring within tattoos have been reported, including cases of keratoacanthoma (KA) developed on red ink. ${ }^{2}$ Pathogenesis of KA on tattoos remains unclear, and is probably due to multiple factors: trauma induced by the needle during the tattoo itself, inflammatory reactions, ultra-violet radiation, direct carcinogenicity of the tattoo inks and individual background., ${ }^{2,3}$

Direct analysis of the composition of tattoo inks at the site of skin cancer could therefore be very interesting, but to our knowledge, this type of analysis has never been conducted before. We report the precise organic and inorganic chemical composition and distribution of tattoo inks within three cases of tattoo associated KA.

Clinical and histopathological data from three patients diagnosed with tattoo associated KA in 2017 were collected in Bichat H. These data were completed by structural and chemical characterisation of tattoo inks within KA, using Raman spectroscopy, to identify the organic 
compounds of tattoo inks and Synchrotron-based measurements - including X-ray fluorescence spectroscopy (XRF) and X-ray Absorption Near Edge Spectroscopy (XANES) to identify the inorganic compounds. ${ }^{4,5}$

All three patients developed KA on red ink within several weeks following the tattoo set-up procedure. For one patient, black and yellow inks were also used for the tattoo. A typical histopathological aspect of KA was observed in all three cases, associated with the presence of intra-dermal colored pigments, located in the direct periphery of the tumoral mass.

Raman spectroscopy identified the same organic compound on all three samples. This Raman spectrum was compared to previous published data and to a reference dye sample (Kremer), allowing the identification of Pigment Red 170 (PR170). ${ }^{6}$ Raman spectroscopy also showed the presence of the rutile polymorph of Titanium dioxide $\left(\mathrm{TiO}_{2}\right)$ particles for one patient who presented a KA on a lighter shade of red (Fig. 1). ${ }^{7}$

Synchrotron-based measurements identified Iron and Zinc oxide in all three sample and Titanium oxide in one sample. A detailed analysis of XRF data showed that the spatial distribution of Titanium was remarkably correlated to the position of the tumor (Fig. 2e). In order to describe the chemical phase of Iron and Zinc oxide and confirm the exogenous origin of these oxides, XANES analysis was performed, identifying zincite and goethite. ${ }^{8}$

We report the description of both the organic and inorganic chemical composition of tattoo inks in cases of KA. Our analyses demonstrated the presence of the same red azo pigment (PR170) in all three KA, consistently associated with metal oxide. Spatial correlation between both PR170, metal oxide, and the tumor was found in all cases. 
Genesis of PAA from azo pigments such as PR170 in humans is suspected to be the consequence of enzymatic activity, thermal decomposition, or photodegradation, after UV light exposure. ${ }^{9}$ Metal oxides are efficient photocatalysts and could have potentiated photodegradation of PR170 in our cases. ${ }^{10}$

Presence of PR170 in these three KA raises the question of the carcinogenecity of this substance. Interestingly, PR170 is not listed by the European Council as a carcinogenonic azo-colorants. Analysis of more cases of skin cancer within tattoos using the same techniques would allow a better identification of potential carcinogenic compounds and help render tattoo ink composition safer.

\section{References}

1. Laux P, Tralau $\mathrm{T}$, Tentschert $\mathrm{J}$ et al. A medical-toxicological view of tattooing. Lancet. 2016; 387: 395-402.

2. Kluger N, Douvin D, Dupuis-Fourdan F, Doumecq-Lacoste JM, Descamps V. Keratoacanthomas on recent tattoos: Two cases. Ann Dermatol Venereol. 2017;144:776-783.

3. Kluger N, Koljonen V. Tattoos, inks, and cancer. Lancet Oncol. 2012; 13: e161-168.

4. Yakes BJ, Michael TJ, Perez-Gonzalez M, Harp BP. Investigation of tattoo pigments by Raman spectroscopy: Investigation of tattoo pigments by Raman spectroscopy. $J$ Raman Spectrosc. 2017; 48: 736-743.

5. Reguer S, Mocuta C, Thiaudière D, Daudon M, Bazin D. Combination of X-ray synchrotron radiation techniques to gather information for clinicians. Comptes Rendus Chimie. 2016; 19: 1424-1431. 
6. Scherrer NC, Stefan Z, Francoise D, Annette F, Renate K. Synthetic organic pigments of the 20th and 21st century relevant to artist's paints: Raman spectra reference collection. Spectrochim Acta A Mol Biomol Spectrosc. 2009; 73:505-524.

7. Frank O, Zukalova M, Laskova B, Kürti J, Koltai J, Kavan L. Raman spectra of titanium dioxide (anatase, rutile) with identified oxygen isotopes $(16,17,18)$. Phys Chem Chem Phys. 2012; 14: 14567.

8. Dessombz A, Nguyen C, Ea H-K et al. Combining $\mu$ X-ray fluorescence, $\mu$ XANES and $\mu \mathrm{XRD}$ to shed light on $\mathrm{Zn} 2+$ cations in cartilage and meniscus calcifications. $J$ Trace Elem Med Biol. 2013; 27: 326-333.

9. Hauri U, Hohl C. Photostability and Breakdown Products of Pigments Currently Used in Tattoo Inks. Tattooed Skin and Health. Karger Publishers, 2015; 164-169.

10. Xue $\mathrm{C}, \mathrm{Wu} \mathrm{J}$, Lan $\mathrm{F}$ et al. Nano titanium dioxide induces the generation of ROS and potential damage in HaCaT cells under UVA irradiation. J Nanosci Nanotechnol. 2010; 10: 8500-8507. 

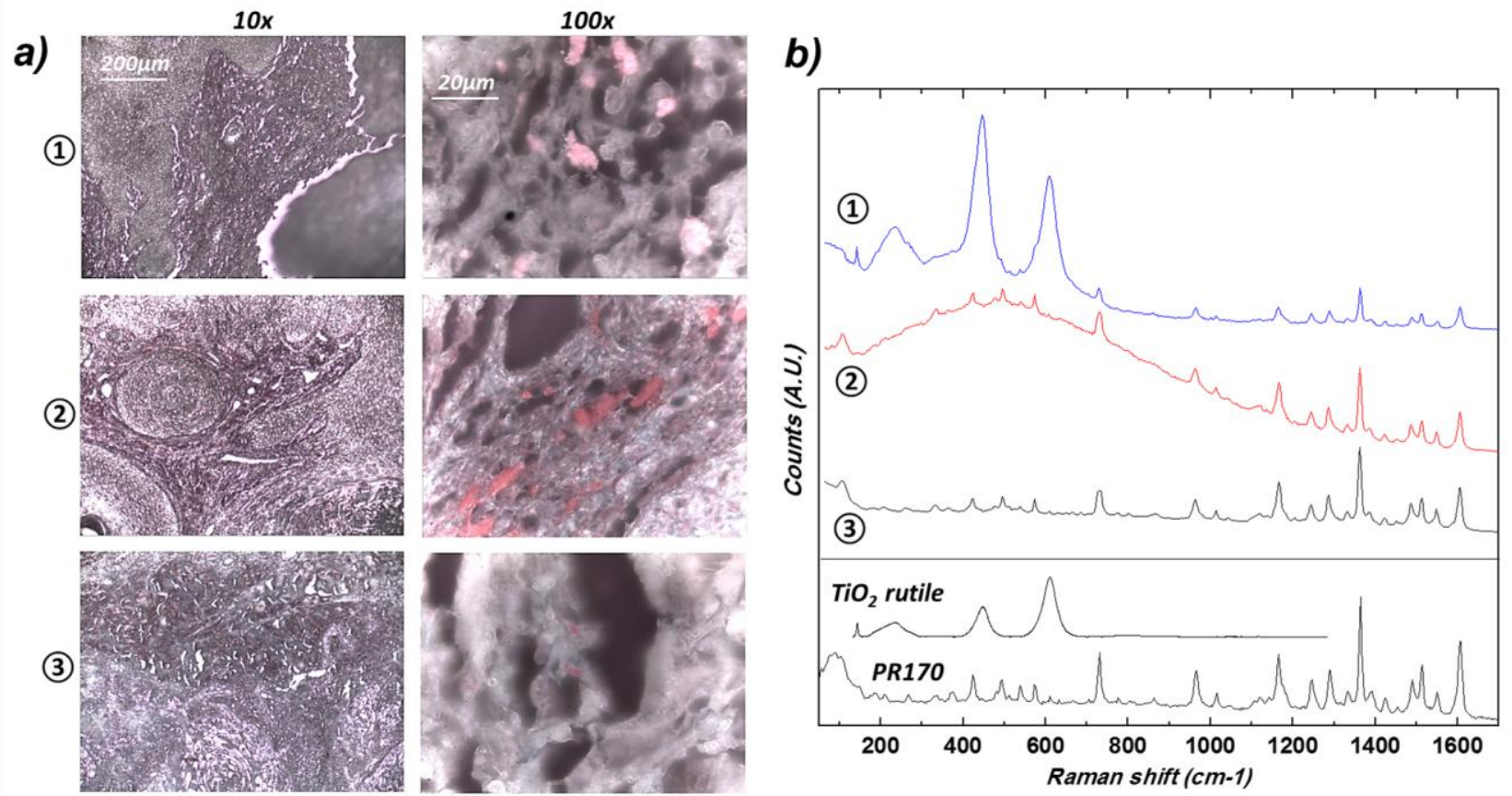

Fig 1. a) Optical micrographs of the three samples at two different magnifications (10X and 100X) revealing the presence of micron size red pigment clusters. On patient 1 , note the heterogenous and lighter aspect of the red pigment, suggesting the presence of nanoparticles of $\mathrm{TiO}_{2}$. b) Corresponding Raman spectra. Reference spectra are also given as comparison: PR170 dye sample (Kremer) and rutile $\left(\mathrm{TiO}_{2}\right)$ downloaded from the RRUFF database. 


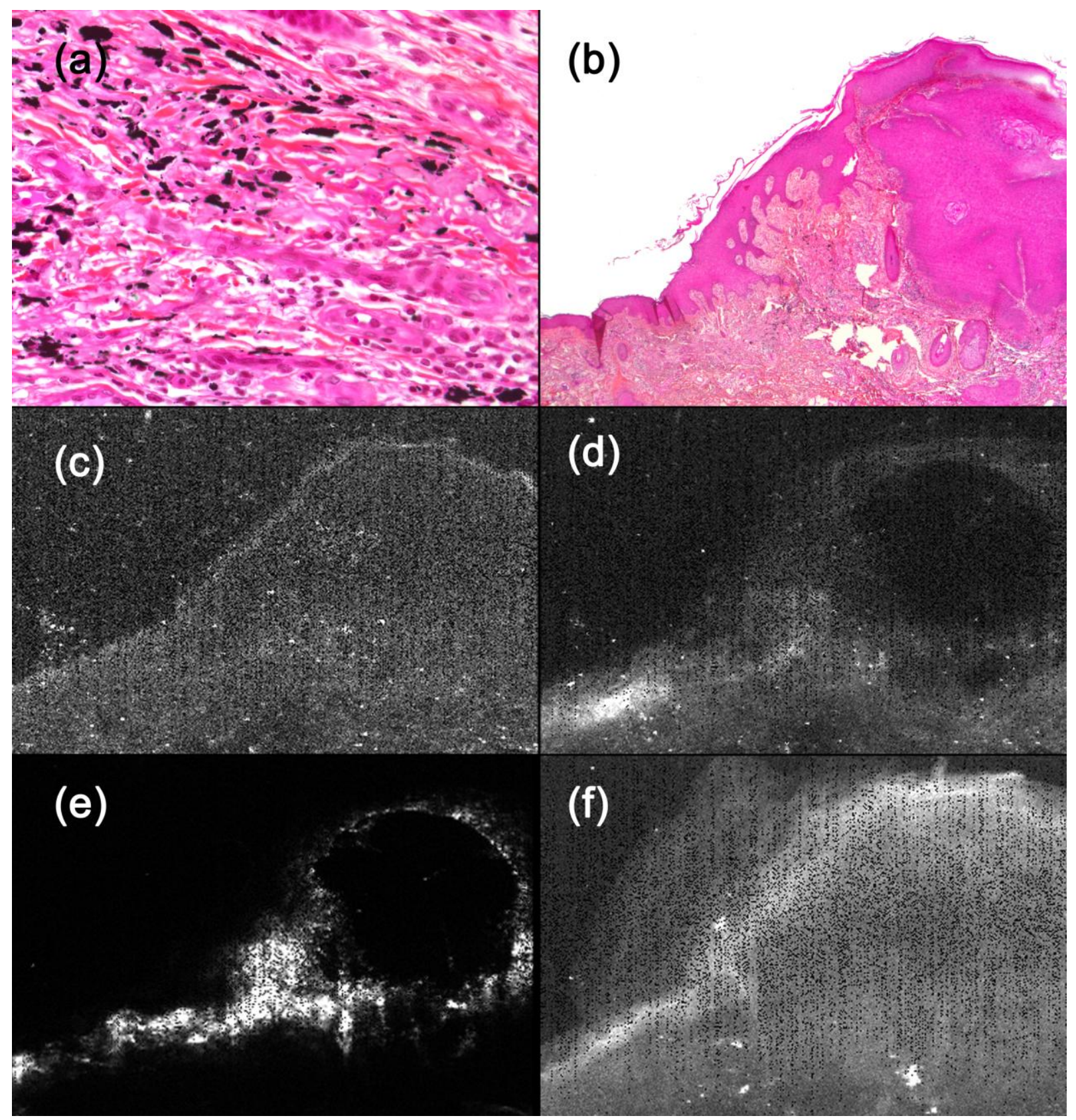

Fig 2. Optical microscopy and XRF correlation: Optical microscopy, showing mainly black ink in the superficial and deep dermis, with little, dispersed, and less visible, pink ink: a) Hematoxylin-eosin-saffron (HES)-stained (x400) b) HES-stained (x25). XRF analysis: The main elements observed are c) $\mathrm{Ca}$, d) Fe e) Ti and f) Zn. 
